\title{
Thermally Modified Wood for Use in Musical Instruments
}

\section{Toplinski modificirano drvo za izradu glazbenih instrumenata}

\author{
Review paper $\bullet$ Pregledni rad \\ Received-prispjelo: 21. 8. 2014. \\ Accepted-prihvaćeno: 20. 5. 2015. \\ UDK: $630 * 835.2 ; 630 * 842$ \\ doi:10.5552/drind.2015.1426
}

\begin{abstract}
The unique mechanical and acoustical properties of wood and its aesthetic appeal still make it the material of choice for musical instruments. Here tropical hardwoods are typically used in musical instruments. This paper gives an overview of how the use of thermally modified wood can contribute to the use of raw materials for musical instruments. It is shown that a mild thermal treatment leads to clear changes of the measurable acoustic characteristics, such as Young's modulus, damping and sound velocity. In conclusion, thermally modified wood (mild treatment) is a material with favorable characteristics for making musical instruments.
\end{abstract}

Key words: acoustical wood properties, musical instruments, thermally modified wood

SAŽETAK • Zbog jedinstvenih mehaničkih i akustičnih svojstava te estetskih obilježja drvo se često rabi kao materijal za izradu glazbenih instrumenata. U radu se opisuje kako uporaba toplinski modificiranog drva može pridonijeti boljoj raspoloživosti sirovine za izradu glazbenih instrumenata. Pokazalo se da blaga toplinska obrada drva dovodi do jasnih promjena mjerljivih akustičnih veličina kao što su Yangov modul elastičnosti, prigušenje $i$ brzina zvuka. Zaključno, drvo koje je umjereno toplinski modificirano ima poželjna obilježja za izradu glazbenih instrumenata.

Ključne riječi: akustična svojstva drva, glazbeni instrumenti, toplinski modificrano drvo

\section{INTRODUCTION \\ 1. UVOD}

The unique mechanical and acoustical properties of wood and its aesthetic appeal still make it the material of choice for musical instruments. Worldwide, several hundred wood species are available for making wind, string, or percussion instruments (Wegst, 2006). Here tropical hardwoods are typically used in musical instruments. Examples for tropical hardwoods in musical instruments are:

- Ebony (e.g. fretboards)

- Brazilian rosewood (e.g. bottom and ribs of guitars)

- Mahogany (e.g. in guitars and violins)
- Páu brasil (Pernambuco) (bows of stringed instruments)

- Grenadilla (e.g. flute and clarinets)

These wood species are often illegally cut down. Some species (e.g. Brazilian Rosewood, some Mahogany species, Pernambuco) are protected by CITES (Convention on International Trade in Endangered Species). Today, the demand increases to replace tropical wood in musical instruments. The search for alternative wood has to take into consideration anatomical features, physical, mechanical, acoustical, and chemical properties.

On the other hand, the desire of musical instrument manufactures to reduce negative characteristics

${ }^{1}$ Author is professor at Eberswalde University for Sustainable Development - University of Applied Sciences, Eberswalde, Germany.

'Autor je profesor Sveučilišta održivog razvoja u Eberswaldu - Sveučilište primijenjenih znanosti, Eberswalde, Germany. 
of the raw material wood by special modification processes has existed for a century now. An overview of different historical modification processes can be found in the paper by Martius (1999). Many of these processes were not further pursued. Today, however, the question arises whether some of these historical procedures, with consideration of new, further developed methods, can help to satisfy the increasing demand of high-quality wood for musical instruments.

This paper gives an overview of how the use of thermally modified wood can contribute to the use of raw material for musical instruments.

\section{OVERVIEW}

\section{PREGLED LITERATURE}

In some scientific papers, the effect of heat treatment upon the acoustic properties of wood are described. Gadd and D'Arcy (1986) state that the heat treatment of spruce gives no statistically significant effect on characteristic values of wood. Such treatments, with temperatures between $110^{\circ} \mathrm{C}$ and $115^{\circ} \mathrm{C}$, result only in slight changes in material properties.

A study with several producers of guitars from Finland, conducted between 1998 and 2002, shows the use of thermally modified wood, made by the finish VTT process, in musical instruments. It was clearly observed that the treatment temperature affects the achieved sound velocity of wood samples. The conclusion of this research is that when tonewoods are thermally treated in a specific manner, the changes in wood are the same as in naturally aged wood, whereas certain qualities of wood improve while the wood maintains its workability and strength. Further, the benefits of thermal-treatment seem more apparent when wood species of higher quality are treated (results published in Thompson, 2006).

Obataya et al. (2003, 2006a, 2006b) showed the influence of high temperature kiln drying on the practical performances of Japanese cedar wood. This heat treatment is sometimes regarded as an accelerated ageing. However, heat-treated wood and aged wood are qualitatively different with respect to their hygroscopicity and vibrational properties.

The aim of the work of Pfriem et al. (2005) and Wagenführ et al. (2006) was to compare thermally modified and unmodified twin samples of resonance spruce wood for sound boards. By a specific thermal treatment, physical-technical characteristics of wood can be changed in such a way that they correspond better to the requirements of wood used for sound boards than unmodified woods. More serious is the reduced moisture sorption, larger dimensional stability, better durability as well as acoustic characteristics. The effects of the relatively mild thermal treatment $\left(180^{\circ} \mathrm{C}\right)$ can be compared with an "artificial aging". Due to the thermal modification, objectively measurable parameters are improved, and hence it can be concluded that sound characteristics are improved, too.

Pfriem (2006) and Pfriem et al. (2007) built and tested musical instruments made with thermally modi- fied wood. For the purpose of this study, guitars, violins, and harmonicas (partly) made from thermally modified wood were prepared and tested. The analysis of possible application areas in musical instruments was not only in the foreground of this investigation. Rather, the physical changes of material behavior caused by thermal modification were investigated with special reference to the general requirements for making instruments.

Mohebby et al. (2007) investigated the influence of hydrothermal modification on musical properties of mulberry wood. This wood is used traditionally for making instruments in Iran. Due to the improved hydrophobicity and dimensional stability, sound properties became better by hydrothermal modification.

Investigations focused on the use of thermally modified wood for statically and dynamically highly stressed components of musical instruments were carried out by Zauer and Pfriem (2010). The cross sections of thermally modified maple (Acer pseudoplatanus L.) were reinforced with carbon fibers reinforced epoxy resin in a single-stage process. The results clearly show that thermal treatment improves the sound quality of wood. Additionally, the reinforcement with carbon fiber increases the static and dynamical properties of thermally modified wood.

Zauer et al. (2014) modified European beech (Fagus sylvatica L.) to increase the acoustic and mechanical properties similar to Hard maple (Acer saccharum) to substitute the latter especially in highly stressed components of musical instruments. A relatively mild treatment, at temperatures ranging between $140{ }^{\circ} \mathrm{C}$ and $160{ }^{\circ} \mathrm{C}$ and a treatment time of $12 \mathrm{~h}$, leads to an improvement of both mechanical and acoustical properties of beech wood. E.g. the average damping values of beech wood were improved to the level of hard maple wood by this mild treatment procedure. The materials may be used as substitution material in electric guitars.

\section{CONCLUSIONS 3. ZAKLJUČAK}

Apart from a change of the acoustically relevant characteristics, thermally modified wood exhibits advantages concerning the dimensional stability and sorption in regard to changing climatic conditions. On the other hand, the modification of wood at high temperatures results in a reduction in strength and toughness. Certainly, a mild thermal treatment (modifying at $160-180{ }^{\circ} \mathrm{C}$ in oxygen-poor atmosphere) leads to clear changes of the measurable acoustic characteristics, such as Young's modulus, damping and sound velocity. In conclusion, thermally modified wood (mild treatment) is a material with favorable characteristics for making musical instruments. A pre-selection of raw materials is, however, absolutely necessary. Inappropriate materials can hardly be improved by thermal modification. Due to these investigations, traditional production technologies for making musical instruments can be adapted to use thermally modified wood 
in musical instruments. For thermally modified wood (mild treatment), three application areas are possible:

- Use in instruments, where high dimensional stability and low moisture sorption and reduced reaction to climatic variability are required.

- Use in musical instruments, where specific sound characteristics are required, which otherwise can only be attained by use of wood stored for a very long time. A reduction of storage time and in that way a significant saving on storage costs can be obtained. Thermally modified wood will not replace wood used so far, but it can be a successful supplement. Through the use of thermally modified wood, the assortment of musical instrument manufacturers can be widened or extended.

- Since the thermally improved wood shows similar sound characteristics to naturally aged wood, it is suited for the restoration and reconstruction of old musical instruments.

In addition, based on the results obtained, it can be concluded that thermally modified timber can also be used for other applications. As musical instruments represent the "upper class" in the wood processing industry, such statements regarding the workability and usability can also be applied to other areas.

\section{REFERENCES}

\section{LITERATURA}

1. Gadd, C.; D'Arcy, J., 1986: On the effect of heat treatment upon acoustic properties of spruce. Journal of the Violin Society of America, 7 (4): 157-166.

2. Martius, K., 1999: Herkunft, Lagerung und Präparation von Tonhölzern im Spiegel historischer Quellen. Scripta Artium 1: 23-34.

3. Mohebby, B.; Yaghoubi, K.; Roohnia, M., 2007: Acoustic Properties of Hydrothermally Modified Mulberry (Morus alba L.) Wood. Proceedings of the third European Conference on Wood Modification, Cardiff, 283-286.

4. Obataya, E.; Higashihara, T.; Gril, J., 2003: Effects of heat treatment on the hygroscopicity of wood. Proceeding of the Second International Conference of the European Society for Wood Mechanics, Stockholm, 33-37.

5. Obataya, E.; Shibutani, S.; Hanata, K.; Doi, S., 2006a: Effects of high temperature kiln drying on the practical performances of Japanese cedar wood (Cryptomeria japonica D. Don) I: changes in hygroscopicity due to heating. Journal of Wood Science, 52(1): 33-38. http://dx.doi.org/10.1007/s10086-005-0716-9
6. Obataya, E.; Shibutani, S.; Hanata, K.; Doi, S., 2006b: Effects of high temperature kiln drying on the practical performances of Japanese cedar wood (Cryptomeria japonica D. Don) II: changes in mechanical properties due to heating. Journal of Wood Science, 52(2): 111-114. http://dx.doi.org/10.1007/s10086-005-0748-1

7. Pfriem, A.; Wagenführ, A.; Ziegenhals, G.; Eichelberger, K., 2005: Use of wood performed by heat-treatment for musical instruments. Proceedings of the Second European Conference on Wood Modification, Göttingen, 390-397.

8. Pfriem, A., 2006: Untersuchungen zum Materialverhalten thermisch modifizierter Hölzer für deren Verwendung im Musikinstrumentenbau. Ph.D. thesis TU Dresden.

9. Wagenführ, A.; Pfriem, A.; Grothe, T.; Eichelberger, K., 2006: Untersuchungen zur vergleichenden Charakterisierung von thermisch modifizierter Fichte für Resonanzdecken von Gitarren. Holz als Roh- und Werkstoff, 64: 313-316. http://dx.doi.org/10.1007/s00107-005-0057-9

10. Pfriem, A.; Eichelberger, K.; Wagenführ, A., 2007: Acoustic properties of thermally modified spruce for use for violins. Journal of the Violin Society of America: VSA-Paper 21(1): 102-111.

11. Thomson, H. S., 2006: Thermo-treated Wood... Vintage Tone or Voodoo from Finland? The ToneQuest, 7(3): 11-16.

12. Wegst, U., 2006: Wood for Sound. American Journal of Botany, 93(10): 1439-1448. http://dx.doi.org/10.3732/ajb.93.10.1439

13. Zauer, M.; Pfriem, A., 2010: Reinforcement of Thermally Modified Wood for Use in Highly Stressed Components of Musical Instruments. Proceedings of the fifth European Conference on Wood Modification ECWM5, Riga, 31-38.

14. Zauer, M.; Sproßmann, R.; Wagenführ, A., 2014: Improvement of the acoustic properties of European beech to substitute hard maple for the use in musical instruments. Proceedings of the Seventh European Conference on Wood Modification ECWM7, Lisboa, Portugal.

\section{Corresponding address:}

\section{Prof. Dr.-Ing. ALEXANDER PFRIEM}

Eberswalde University for Sustainable Development University of Applied Sciences

Professorship Wood Chemistry, Wood Physics and Chemical Engineering

Schicklerstraße 5

16225 Eberswalde, GERMANY

e-mail: alexander.pfriem@hnee.de 